Check for updates

Cite this: RSC Adv., 2018, 8, 28405

\title{
The sustainable synthesis of peptidomimetics via chemoenzymatic tandem oxidation-Ugi reaction $\uparrow$
}

\author{
Arleta Madej, Dominik Koszelewski, Daniel Paprocki, Anna Brodzka \\ and Ryszard Ostaszewski (D) *
}

A simply and green synthetic protocol based on the selective laccase-oxidation of alcohol to a corresponding aldehyde and a following Ugi reaction in a micellar system made of SDS was developed and is reported herein. Special emphasis was placed on the metal-free chemoenzymatic tandem reaction based on alcohol oxidation strategies using molecular oxygen from air, followed by an Ugi reaction. The reaction was carried out without the use of a transition metal or organic solvents as a reaction medium. The presented protocol offers an efficient and environmentally friendly procedure.

Received 29th May 2018

Accepted 26th July 2018

DOI: $10.1039 / c 8 r a 04583 f$

rsc.li/rsc-advances

combined in a one-pot procedure (Scheme 1). ${ }^{17-19}$ Che et al.

\section{Introduction}

The sustainable synthesis of peptidomimetics is still a challenge for green chemistry. ${ }^{1}$ One of the methods used for the synthesis of these compounds relies on an Ugi reaction, which is recognized as an advanced tool for sustainable organic synthesis. ${ }^{2}$ The Ugi reaction is atom efficient since only one molecule of water is lost from the starting materials during the reaction. ${ }^{3}$ It has significant potential in molecule formation, which has seen it continuously used in the field of medicinal chemistry. ${ }^{4,5}$ The first example of the application of $\alpha$-aminoacyl amides in pharmaceuticals was the local anesthetic xylocaine obtained in a one-pot Ugi reaction. ${ }^{6}$ Moreover, this type of reaction was used by process chemists at Merck for the production of the blockbuster anti-HIV drug Crixivan. ${ }^{7}$

As carbonyl reagents for the Ugi reaction, aldehydes or ketones are used. Owing to the increasing need for more economic and environmentally friendly synthetic protocols, the development of tandem oxidative processes combining an alcohol oxidation with a multicomponent reaction is actually of great interest. ${ }^{8-10}$

The generation of an aldehyde in situ in the reaction mixture allows overcoming some of the disadvantages, e.g., instability during storage leading to the formation of the corresponding alcohols, carboxylic acids, and other impurities. ${ }^{11}$ A great number of systems for the oxidation of alcohols to aldehydes, including TPAP (tetrapropylammonium perruthenate) ${ }^{12,13}$ and copper ${ }^{14-16}$ catalyses, are known.

It has been proved that the oxidation system is compatible with multicomponent reaction conditions and therefore can be

Institute of Organic Chemistry, Polish Academy of Sciences, Kasprzaka 44/52, 01-224 Warsaw, Poland. E-mail: ryszard.ostaszewski@icho.edu.pl

$\dagger$ Electronic supplementary information (ESI) available. See DOI: 10.1039/c8ra04583f described the oxidation of secondary amines to imines by singlet oxygen (generated from oxygen and the porphyrin photosensizer), followed by the Ugi reaction..$^{20}$ Recently, Zhu et al. reported the tandem oxidation of alcohols using $o$-iodoxybenzoic acid (IBX) or Oxone ${ }^{\circledR}$ in the presence of a catalytic amount of sodium 2-iodobenzenesulfonate as an oxidant, followed by the Ugi (U-4CR) reaction (Scheme 1). ${ }^{21,22}$ One of the main drawbacks of IBX is its shock sensitivity, and limited solubility in many common organic solvents. ${ }^{23}$ For this purpose, to keep the reaction mixture homogeneous, a high dilution is required for the oxidation conditions, which is inconvenient for multicomponent reactions. ${ }^{24}$

The application of metal complexes for the oxidation of an alcohol generates many impurities, which is intolerable for pharmaceutical or the cosmetic industry. This was justified by the fact that pharmacopeia limits of heavy metal contaminations are below $5 \mathrm{ppm}$. Therefore, most classical chemical methods applying metal catalysts are unacceptable. ${ }^{25}$

In order to overcome the existing limitations in the currently used experimental procedures to synthesize pollutants-free peptidomimetics, a new strategy is proposed herein. For the oxidation of alcohols, enzymatic oxidation can be used, which

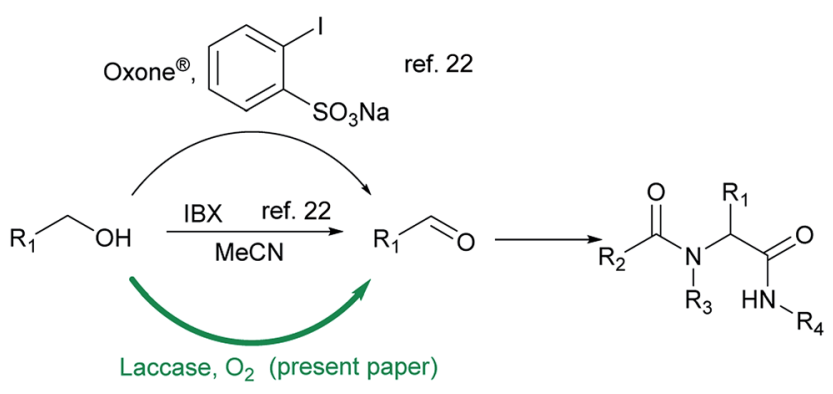

Scheme 1 Methods used for the synthesis of peptidomimetics based on a tandem oxidation-Ugi reaction. 


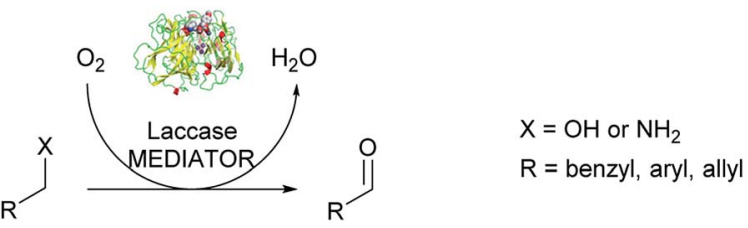

Scheme 2 Schematic representation of LTV/TEMPO oxidation.

may be further combined with an Ugi reaction to provide the target compounds. In this system, water can be used as a solvent since both reactions proceed efficiently in this solvent. ${ }^{26}$

Water is cheap, safe and leads to the progress in environmentally safe chemical synthesis. ${ }^{27,28}$ However, water is not a perfect solvent due to the insolubility or low solubility of most organic compounds. In order to enhance the solubility of substrates, surfactants (surface active agents) as amphiphilic molecules can be used. ${ }^{29-31}$

For the oxidation of alcohols, the group of multi-copper oxidases, such as laccases (EC 1.10.3.2), show miscellaneous biochemical properties. Some are known for the oxidation of a wide range of electron-rich compounds, e.g., phenols, ${ }^{32}$ allylic alcohols, ${ }^{33,34}$ and aromatic alcohols, ${ }^{35-37}$ or amines ${ }^{38}$ using air oxygen as an electron acceptor (Scheme 2).

Enzymatic and micellar catalysis have been intensively investigated in our group and our ongoing studies are part of the research devoted to Ugi multicomponent reactions performed in aqueous media. ${ }^{39}$ In the present paper, we focus our attention on the chemoenzymatic tandem oxidation-Ugi reaction in a micellar system. Herein, we report a straightforward metal-free protocol for the synthesis of $\alpha$-acylamino amides via the oxidation of primary alcohols by laccase from a Trametes versicolor (LTV)/TEMPO system, followed by an Ugi reaction. In the first step, the primary alcohol is selectively oxidized to an aldehyde by oxygen from air (without the usage of $\mathrm{O}_{2}$, which is potentially explosive), applying LTV as a catalyst and TEMPO as a mediator. Afterward, the formed aldehyde was applied in an Ugi reaction with carboxylic acid, amine, and isocyanide. Both reactions could be performed in an aqueous surfactant system, with increase productivity, without the need for the addition of an organic solvent or transition metal, which is beneficial from an environmental point of view.

\section{Results and discussion}

As components for the model chemoenzymatic tandem oxidation-Ugi reaction, benzyl alcohol (1a), $p$-methoxybenzylamine (3a), phenylacetic acid (4a), and $p$-methoxybenzyl isocyanide (5a) were selected. According to the literature data, benzyl alcohol (1a) is compatible with laccase-catalyzed oxidation, providing the corresponding aldehyde 2a exclusively. ${ }^{40,41}$ Recently, we proved that the Ugi reaction can be conducted in DDAB (didodecyldimethylammonium bromide) micelles. ${ }^{39}$

In present studies, we turned our attention to an aerobic oxidation of benzyl alcohol (1a) to benzaldehyde (2a) catalyzed by laccase from Trametes versicolor (LTv). We investigated the influence of didodecyldimethylammonium bromide (DDAB) on the reaction in the presence of LTV and TEMPO. For this purpose, we performed two parallel reactions: the oxidation of benzyl alcohol 1a in the presence and absence of DDAB. Both reactions were stirred overnight at room temperature. TLC analyses in both cases showed a full conversion to benzaldehyde (2a) exclusively. The experiments showed that an aerobic oxidation of benzyl alcohol could be performed efficiently in the presence of a surfactant. This observation encouraged us to combine this system with an Ugi-four component reaction (U4CR). Recently, we presented the chemoenzymatic tandem oxidation-Passerini reaction based on the laccase-catalyzed oxidation of benzyl alcohol. ${ }^{17}$ Herein, we examined an analogous approach with the more demanding, four component Ugi reaction. For gaining more insights into the effect of the surfactant on the Ugi reaction, the condensation of benzaldehyde (2a) $p$-methoxybenzylamine (3a), phenylacetic acid (4a), and $p$-methoxybenzyl isocyanide (5a) in the presence of DDAB in phosphate buffer (PBS) pH 5.2 was investigated. The model product $6 \mathbf{a}$ was obtained with a $35 \%$ yield. Next, we performed the tandem oxidation-Ugi reaction in the presence of DDAB. The reaction was stirred overall for $72 \mathrm{~h}$ at room temperature, leading to $6 \mathbf{a}$ with a $30 \%$ yield.

For the first $24 \mathrm{~h}$, enzymatic oxidation took place and next the rest of the substrates for the Ugi reaction were added. Due to the fact that oxidation, which is the first step of the chemoenzymatic tandem reaction, in the presence of surfactants is quantitative, the obtained yield of the target 6a was not satisfying. Therefore, we wondered if DDAB was likewise optimal for chemoenzymatic tandem reaction or only for the separated steps.

Furthermore, we investigated the influence of different types of surfactants (20 mol\%) on the model Ugi reaction, with 1a, 3a, 4a, 5a as the substrates in the presence of LTv, TEMPO, in PBS $\mathrm{pH}$ 5.2. In all cases, the surfactants were used in the amount above their cmc (critical micellar concentration). ${ }^{42}$ The collected results indicated that SDS is optimal for the tandem Ugi reaction and was thus used in the further studies (Table 1).

The literature data show that the type of mediator and reaction time have a great influence on the alcohol oxidation by the laccase. For this reason, HOBt was also tested as a mediator instead of TEMPO. ${ }^{43}$ However, when HOBt was applied, the formation of any product was observed (Table 2, entry 8 ). In the next step, we investigated the influence of time on the reaction course. The optimal time for the chemoenzymatic tandem reaction was $72 \mathrm{~h}$, affording product 6a with a $45 \%$ yield (Table 2 , entries 4-7). Further prolongation of the reaction time did not affect the reaction yield. We also tested the impact of other parameters, such as the mediator and enzyme, on the studied chemoenzymatic tandem reaction (Table 2, entries 1 and 2). When one of the mentioned components of the studied reaction was absent, the formation of the desired product 6a was not observed. The addition of SDS enhanced significantly the yield of 6 a from $19 \%$ to $45 \%$ (Table 2, entries 3, 6). The obtained results indicated that the LTV/TEMPO system was the most efficient for the presented tandem reaction.

According to the literature data, the stability and activity of laccase from Trametes versicolor strictly depend on the reaction conditions (e.g., $\mathrm{pH}$, concentration of surfactant, 
Table 1 Effect of different surfactants on the model Ugi reaction ${ }^{a}$

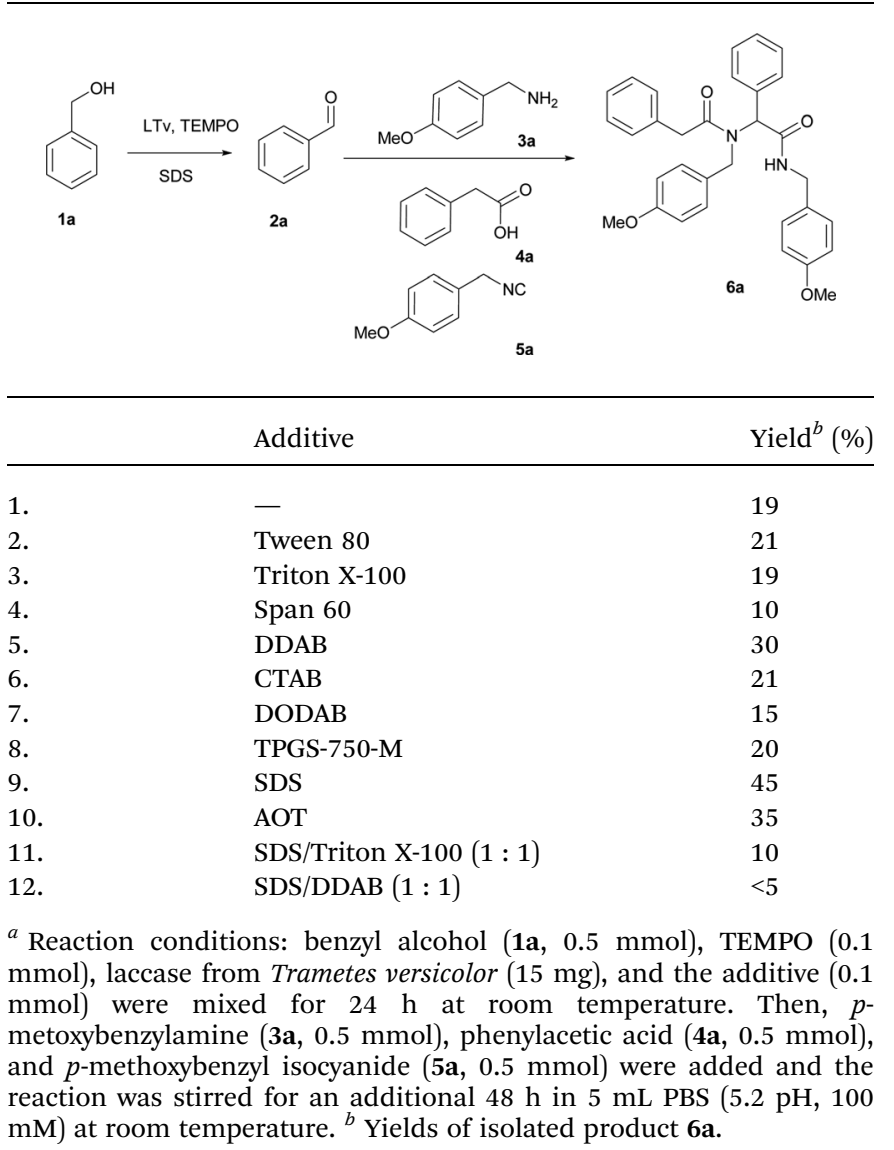

temperature). ${ }^{\mathbf{4 4 - 4 7}}$ It is well known that laccase, which was used in our studies, is active in the $\mathrm{pH}$ range 3.0 to $6.0 .^{\mathbf{4 4 , 4 8}}$ With this data in mind, we tested the optimal $\mathrm{pH}$ for the model reaction. We carried out reactions between the model substrates (1a, 3a, 4a, 5a) in the presence of SDS, TEMPO, and LTv in phosphate buffer in the $\mathrm{pH}$ range between 3.0 and 7.0. The obtained results are given in Fig. 1. Initially, pH 5.2 was

Table 2 Aerobic oxidation of benzyl alcohol (1a) by the LTV/TEMPO system combined with an Ugi reaction ${ }^{a}$

\begin{tabular}{llll}
\hline & Mediator & Time $(\mathrm{h})$ & \multicolumn{1}{l}{ Yield $^{e}(\%)$} \\
\hline 1. & - & 72 & $<1^{b}$ \\
2. & TEMPO & 72 & $\mathrm{ND}^{b, c}$ \\
3. & TEMPO & 72 & $19^{d}$ \\
4. & TEMPO & 24 & $<1^{b}$ \\
5. & TEMPO & 48 & 11 \\
6. & TEMPO & 72 & 45 \\
7. & TEMPO & 96 & 45 \\
8. & HOBt & 72 & $<1^{b}$
\end{tabular}

${ }^{a}$ Reaction conditions: benzyl alcohol (1a, $\left.0.5 \mathrm{mmol}\right)$, mediator ( 0.1 $\mathrm{mmol})$, laccase from Trametes versicolor $(15 \mathrm{mg})$, SDS $(0.1 \mathrm{mmol})$ in $5 \mathrm{~mL}$ PBS $(5.2 \mathrm{pH}, 100 \mathrm{mM})$ for $24 \mathrm{~h}$ at room temperature. Then, $p$ metoxybenzylamine (3a, $0.5 \mathrm{mmol}$ ), phenylacetic acid (4a, $0.5 \mathrm{mmol}$ ) and $p$-methoxybenzyl isocyanide (5a, $0.5 \mathrm{mmol})$ were added. ${ }^{b}$ Estimated by TLC. ${ }^{c}$ Reaction carried out without enzyme. ${ }^{d}$ Reaction carried out without SDS. ${ }^{e}$ Yields of isolated product $\mathbf{6 a}$.

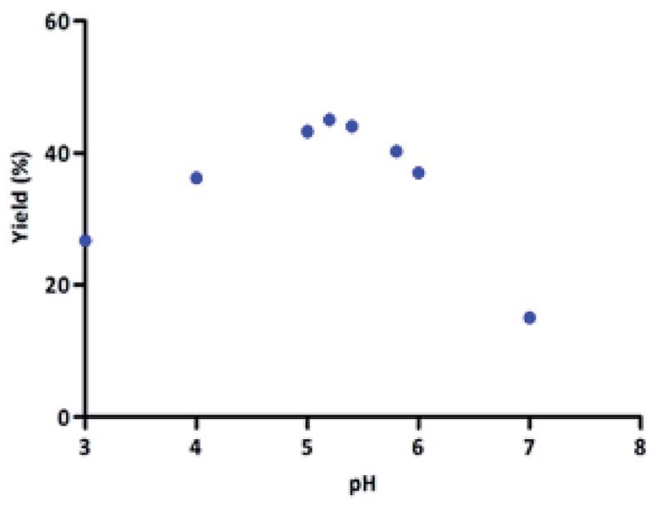

Fig. 1 Effect of $\mathrm{pH}$ on the isolated reaction yield of $6 \mathrm{a}$ of the model laccese/TEMPO oxidation-U4CR system. Reaction conditions: benzyl alcohol (1a, $0.5 \mathrm{mmol})$, TEMPO $(0.1 \mathrm{mmol})$, laccase from Trametes versicolor $(15 \mathrm{mg})$, SDS $(0.1 \mathrm{mmol})$ in $5 \mathrm{~mL}$ PBS $(5.2 \mathrm{pH}, 100 \mathrm{mM})$ were mixed for $24 \mathrm{~h}$ at room temperature. Then, $p$-metoxybenzylamine ( $3 \mathrm{a}$, $0.5 \mathrm{mmol})$, phenylacetic acid $(4 \mathrm{a}, 0.5 \mathrm{mmol})$ and $p$-methoxybenzyl isocyanide (5a, $0.5 \mathrm{mmol}$ ) were added and stirred for an additional $48 \mathrm{~h}$.

optimal for the model tandem LTv/TEMPO oxidation-U4CR one-pot system. Between pH 3.0 and 5.2, the yield of the product $6 \mathrm{a}$ increased to $45 \%$. In the range of $\mathrm{pH} 5.2$ to 6.0 , the yield varied slightly. Above $\mathrm{pH}$ 6.0, the yield of 6a decreased significantly, which can be explained by the lower activity of laccase. ${ }^{48}$

Due to the fact that the concentration of the surfactant can influence the reaction course, we performed additional studies. We investigated the surfactant content (from 0 to $100 \mathrm{~mol} \%$ ) on the chemoenzymatic tandem reaction. The results are presented in Fig. 2. In all cases, the reaction yield in the presence of SDS was higher than in pure PBS. While upon changing the amount of SDS from 0 to $20 \mathrm{~mol} \%$, the yield of product $6 \mathbf{a}$ increased up to $45 \%$. Further elevation of the SDS concentration caused a reduction in the reaction yield to $28 \%(40 \mathrm{~mol} \%$ of

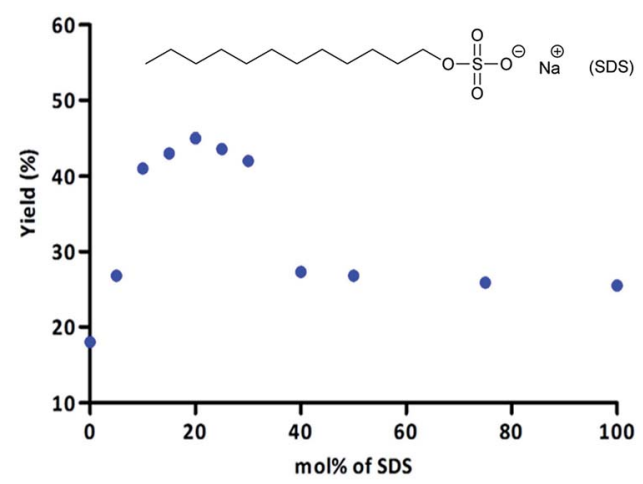

Fig. 2 Effect of SDS on the isolated yield of $6 a$ from the model laccase/TEMPO oxidation-U4CR system. Reaction conditions: benzyl alcohol (1a, $0.5 \mathrm{mmol})$, TEMPO $(0.1 \mathrm{mmol})$, laccase from Trametes versicolor (15 mg), SDS (0.1 mmol) in $5 \mathrm{~mL}$ PBS $(5.2 \mathrm{pH}, 100 \mathrm{mM})$ were mixed for $24 \mathrm{~h}$ at room temperature. Then, $p$-metoxybenzylamine (3a, $0.5 \mathrm{mmol})$, phenylacetic acid $(4 \mathrm{a}, 0.5 \mathrm{mmol})$ and $p$-methoxybenzyl isocyanide ( $5 \mathrm{a}, 0.5 \mathrm{mmol}$ ) were added and stirred for an additional $48 \mathrm{~h}$. 
Table 3 Effect of laccase from Trametes versicolor or TEMPO on the Ugi reaction in the presence of SDS micelles ${ }^{a}$

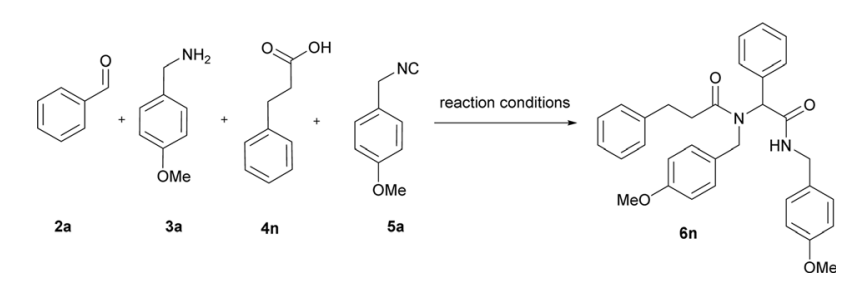

Reaction conditions

Yield of $6 \mathbf{n}^{d}(\%)$

1.

SDS micelles

LTv, SDS micelles

TEMPO, SDS micelles

LTv, TEMPO, SDS micelles

67

$48^{b}$

$20^{c}$

Trace $^{b, c}$

4.

${ }^{a}$ Reaction conditions of benzaldehyde (2a, $\left.0.5 \mathrm{mmol}\right), \quad p$ metoxybenzylamine (3a, $0.5 \mathrm{mmol})$, hydrocynamic acid (4n, 0.5 $\mathrm{mmol}), p$-methoxybenzyl isocyanide $(5 \mathrm{a}, 0.5 \mathrm{mmol})$, SDS $(0.1 \mathrm{mmol})$ in $5 \mathrm{~mL}$ PBS $(5.2 \mathrm{pH}, 100 \mathrm{mM})$ for $48 \mathrm{~h}$ at room temperature. ${ }^{b}$ Laccase from Trametes versicolor $(15 \mathrm{mg}) .{ }^{c}$ TEMPO $(0.1 \mathrm{mmol}) .{ }^{d}$ Yields of isolated product $\mathbf{6 a}$.

SDS). Increasing SDS from 40 to $100 \mathrm{~mol} \%$ did not have any influence on the reaction yield. Due to the collected data of SDS, $20 \mathrm{~mol} \%$ of SDS was selected for the further studies.

Very important from an environmental point of view is the reusability of a catalytic system. Therefore, we investigated if the catalytic system containing the micelles of SDS, LTv, and TEMPO could be used more than once. The filtrate containing the surfactant was used as a medium for the next reaction. The precipitate of $\mathbf{6}$ a was purified by recrystallization from $n$-hexane/ ethyl acetate. The SDS micelles were used for three consecutive reaction cycles. It was found that there was a gradual decrease in reaction yield from $45 \%$ to $10 \%$, probably caused by the loss of surfactant, laccase, or TEMPO during filtration.

After the optimization of the U-4CR, a series of experiments with various alcohols $\mathbf{1}$, carboxylic acids $\mathbf{4}$, and isocyanides 5 was performed, providing $\alpha$-aminoacyl amides $6 \mathbf{a}-6 \mathbf{r}$ (Table 4 ). The isolated yields of 6 were determined after $72 \mathrm{~h}$ at room temperature and were compared with the yields from the Ugi reaction carried out from the corresponding aldehyde (Table 4). For the first part of the experiments, the influence of different alcohols on the chemoenzymatic tandem reaction was investigated. For the reactions carried out with different derivatives of benzyl alcohol $\mathbf{1}$, the products $\mathbf{6 a - 6 f}$ from the Ugi reaction were isolated with yields up to $45 \%$. It was worth noticing that the oxidation of alcohols was quantitative for all the used benzyl alcohol derivatives $(\mathbf{1 a - 1 f})$. The obtained results show that the use of alcohols with electron-withdrawing or electron-donating groups at the aromatic ring did not have a significant impact on enzymatic oxidation and revealed that the yield of the tandem process was limited by the Ugi reaction. The products of allyl alcohol $\mathbf{6 h}$ and ethanol $\mathbf{6 g}$ were not observed. Reactions carried out with aliphatic alcohol, like dodecanol, resulted in the product $6 \mathbf{i}$ with a yield of $11 \%$. According to the literature data, the enzymatic oxidation of aliphatic alcohols catalyzed by LTV does not proceed qualitatively, which results in a low yield of the tandem process. ${ }^{49} \mathrm{Next}$, the influence of different isocyanides 5 and carboxylic acids $\mathbf{4}$ was investigated on the chemoenzymatic tandem reaction. The application of benzyl isocyanide resulted in the product $6 \mathbf{j}$ with a $48 \%$ yield, while the reaction with cyclohexyl isocyanide resulted in product $\mathbf{6 k}$ with a $30 \%$ yield. The use of $n$-butyl and $t$-butyl isocyanides resulted in yields of $35 \%$ of $6 \mathrm{~m}$ and $33 \%$ of 61 , respectively. As can be seen, the developed conditions using SDS promoted the Ugi reaction with aromatic isocyanides as the substrates. Replacing phenylacetic acid with hydrocynamic acid resulted in the product $\mathbf{6 n}$ with a higher yield of $55 \%$ vs. $45 \%$.

However, the application of 4-phenylbutyric acid and 5phenylvaleric acid in the presence of SDS led to products $\mathbf{6 p}$ and 6r with lower yields of $53 \%$ and $45 \%$, respectively, the products 6a-6r were obtained with the SDS micellar system using the corresponding aldehydes in slightly higher yields in most cases than in the chemoenzymatic tandem reaction (Table 4).

To clarify the higher yields of the classical Ugi reaction compared to the chemoenzymatic tandem reaction, additional experiments were performed. The influence of LTV and TEMPO on the classical Ugi reaction in the presence of SDS micelles was examined (Table 3). Benzaldehyde (2a), $p$-methoxybenzyl amine (3a), hydrocynamic acid (4n) and p-methoxybenzyl isocyanide (5a) were stirred in PBS at pH 5.2 in the presence of SDS to give the product $6 \mathrm{n}$ with a $67 \%$ yield (Table 3 , entry 1 ). The addition of LTV or TEMPO to the reaction reduced the yield of $6 \mathbf{n}$ to $48 \%$ and $20 \%$, respectively (Table 3 , entries 2,3 ). In the case when the reaction was performed in the presence of TEMPO and LTV, the product of $\mathbf{6 n}$ was not observed (Table 3, entry 4). Next, we also tested other substrates for the Ugi reaction alone with LTv and TEMPO in the presence of SDS micelles. It is well known that benzyl amine can be oxidized to aldehyde via laccase. ${ }^{50}$ With these data in mind, we verified the substrate $\mathbf{3 a}$ in the presence of LTV, TEMPO, and SDS micelles. The $p$-methoxybenzyl amine was oxidized to $p$-anisaldehyde with a $33 \%$ yield. This indicated that the lower yield in oxidative tandem oxidation-Ugi reaction was the result of the descending concentration of amine during the reaction course performed with laccase. Next, the excess of $p$-methoxybenzyl amine was investigated on the Ugi reaction in micellar media in the presence of LTV and TEMPO. We observed that in the reaction with 2 eq. of $p$-methoxybenzyl amine 3a, benzaldehyde (2a, 1 eq.), hydrocynamic acid (4a, 1 eq.), and $p$-methoxybenzyl isocyanide (5a, 1 eq.) in the presence of SDS micelles enhanced the reaction yield of $6 \mathbf{n}$ to $65 \%$. Also the application of $2 \mathrm{eq}$. of $3 \mathbf{a}$ in the reaction with 1a, $\mathbf{4 n}$, and 5a in the presence of LTv and TEMPO in micellar media resulted in the product $\mathbf{6 n}$ in a higher yield $(60 \%)$.

Furthermore, we wondered whether the laccase transformed the products from the Ugi reaction. In this purpose, the stability of product $6 \mathbf{n}$ was examined. After 6 days, the compound $\mathbf{6 n}$ was recovered with $85 \%$ yield. According to the literature data, the carboxylic acids can form dimers or polymers in the presence of laccase. ${ }^{51}$ Therefore, we verified whether the hydrocynamic acid could react with itself in the presence of TEMPO, LTV, and SDS. However, no new product was observed. It is well known that 
Table 4 Scope and limitation of the LTV/TEMPO oxidation U4CR system
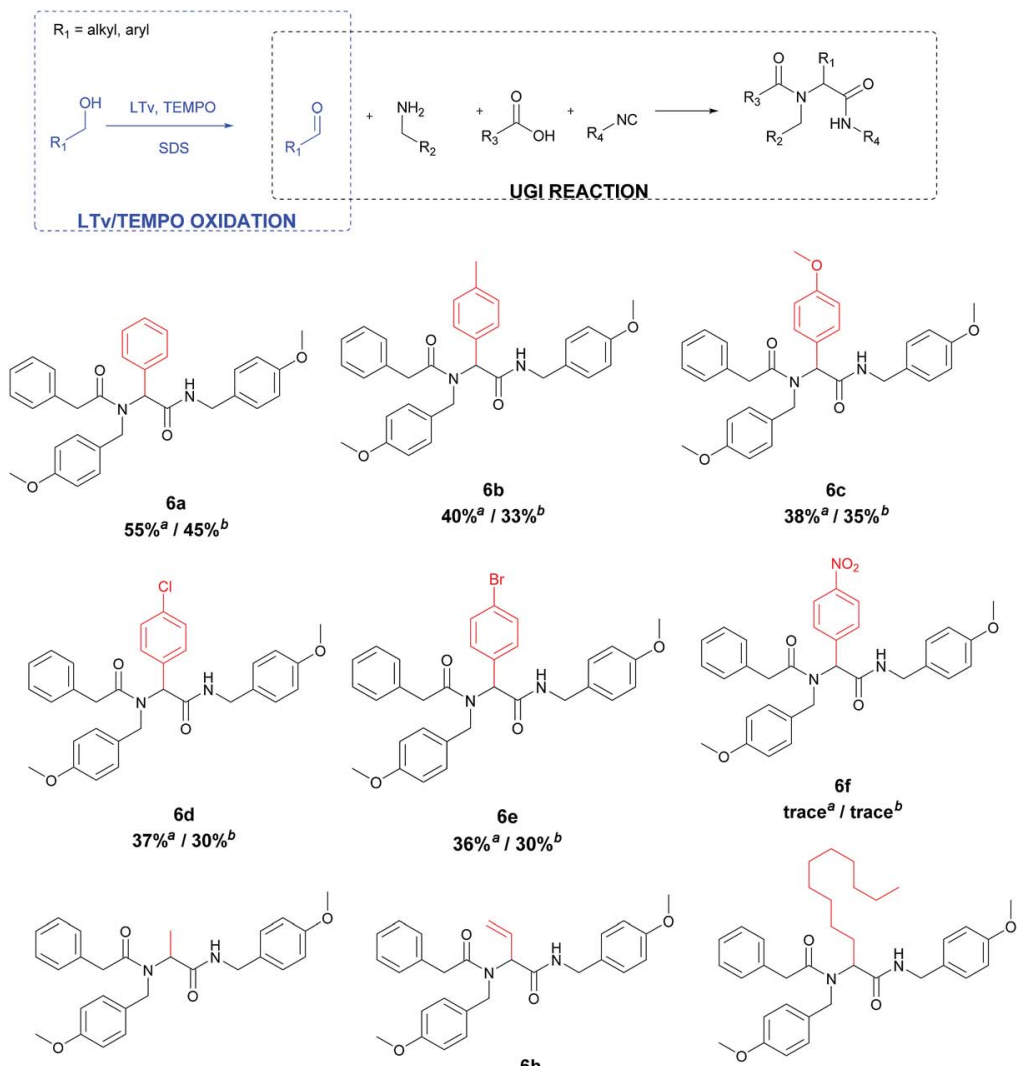

$6 \mathrm{~g}$

$\left.\begin{array}{c}6 h \\ -a\end{array}\right]-b$

$6 \mathbf{i}$

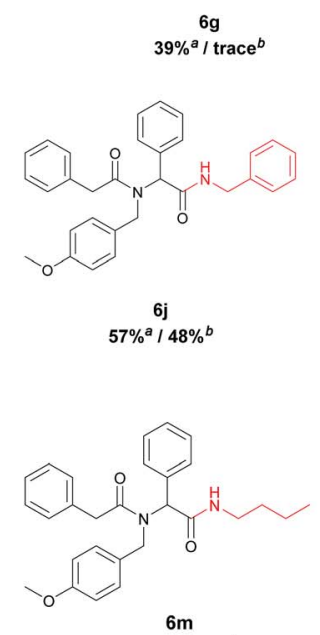

$\underset{50 \%^{a} / 35 \%^{b}}{6}$

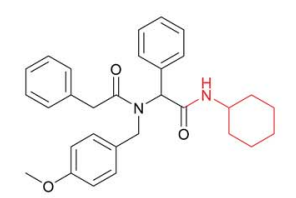

$6 k$
$40 \%^{a} / 30 \%$

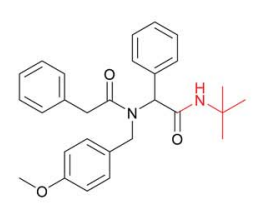

61

$50 \%^{a} / 33 \%^{b}$

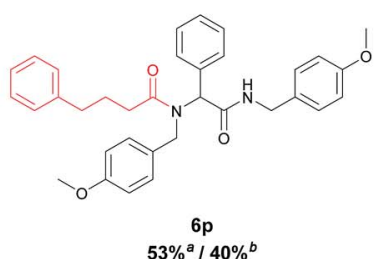<smiles>COc1ccc(CNC(=O)C(c2ccccc2)N(Cc2ccc(OC)cc2)C(=O)CCc2ccccc2)cc1</smiles><smiles>COc1ccc(CN(C(=O)CCc2ccccc2)C(C(=O)NCc2ccccc2)c2ccccc2)cc1</smiles>

$6 n$ 60
$70 \%^{a} / 58 \%^{b}$

$67 \%^{a} / 55 \%^{b}$

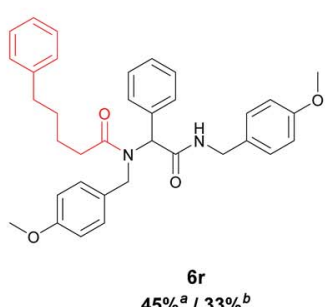

${ }^{a}$ Reaction conditions: aldehyde 2 ( $\left.0.5 \mathrm{mmol}\right)$, amine 3 (1 eq.), carboxylic acid 4 (1 eq.), and isocyanide 5 (1 eq) SDS ( $\left.0.1 \mathrm{mmol}\right)$ in $5 \mathrm{~mL}$ of phosphate buffer (pH 5.2, $100 \mathrm{mM}$ ) were stirred for $48 \mathrm{~h}$ at room temperature. ${ }^{b}$ Reaction conditions: alcohol 1 (0.5 mmol), TEMPO (0.1 mmol), LTv (15 mg), and SDS $(0.1 \mathrm{mmol})$ in $5 \mathrm{~mL}$ of phosphate buffer (pH 5.2,100 mM) were stirred for $24 \mathrm{~h}$ at room temperature. Next, amine 3 (1 eq.), carboxylic acid 4 ( 1 eq.), and isocyanide 5 (1 eq.) were added and the reaction was stirred for an additional $48 \mathrm{~h}$ at room temperature. 
the isocyanides $\mathbf{5}$ have low stability and spontaneous hydrolysis in aqueous solution. ${ }^{52}$ Due to the fact that the synthesis of isocyanides requires a toxic reagent, such as phosphoryl chloride $\left(\mathrm{POCl}_{3}\right)$ their sustainable application is contentious and questionable. To overcome this inconvenience, phase-transfer catalysis (PTC) ${ }^{53}$ was applied, leading to the isocyanide 5a with a $66 \%$ yield. The reaction was performed from $p$-methoxybenzyl amine 3a using $50 \% \mathrm{NaOH}$ solution, $\mathrm{CHCl}_{3}$, and $\mathrm{TBAB}$ (see $\mathrm{ESI}_{\dagger}^{\dagger}$ ).

\section{Conclusions}

We developed a green and environmentally sustainable method for the synthesis of peptidomimetics As substrates, several alcohols were used, which were oxidized by laccase, followed by Ugi reaction providing the target compounds. No transition metal, toxic organic solvents, or harsh oxidants were required. To achieve high substrate solubility, water surfactants were used. The influence of different surfactants on the course of chemoenzymatic tandem Ugi reaction was investigated. We found that the presence of the anionic SDS surfactant had a beneficial effect on the reaction yield compared to pure PBS. During our studies, the optimal concentration and the reusability of SDS were determined. After a detailed optimization of the reaction conditions, the scope of the substrates was evidenced. 17 peptidomimetics of a structure of $\alpha$-aminoacyl amides were obtained and fully characterized. A comparison of the two protocols: chemoenzymatic tandem oxidation-Ugi reaction with classical Ugi reaction in the presence of SDS micelles was made. In most cases, the chemoenzymatic tandem oxidation-Ugi reaction resulted in slightly lower yields, but the products were obtained free from any impurities, which is of great importance for medicinal chemistry applications.

\section{Experimental}

${ }^{1} \mathrm{H}$ NMR and ${ }^{13} \mathrm{C}$ NMR spectra were recorded in $\mathrm{CDCl}_{3}$ with Bruker $400 \mathrm{MHz}$ spectrometers. Tetramethylsilane (TMS) was used as an internal standard. TLC was performed on Kieselgel 60 F254 aluminum sheets. Melting points were determined with a model SMP-20 device from Buchi (Flawil, Switzerland). Fluorescence spectra were recorded in quartz cuvettes with an F7000 spectrofluorometer (Shimadzu, Kyoto, Japan). Laccase from Trametes versicolor, as a powder, light brown, $\geq 0.5 \mathrm{U}$ $\mathrm{mg}^{-1}$, was purchased from Sigma Aldrich, product number 38429.

Almost all the chemicals were commercially available. Only p-methoxybenzyl isocyanide, hexylisocyanide, and 2,4-dimethoxybenzylisocyanide were synthesized from the corresponding amine. Dilauryldimethylammonium bromide (= didodecyldimethylammonium bromide (DDAB), purity > 98.0\%), was purchased from TCI, product number D1974. Dioctadecyldimethylammonium bromide (DODAB), purity $\geq$ 98.0\% (AT), was purchased from Sigma Aldrich, product number 40165. Dioctylsulfosuccinate sodium salt (AOT = sodium bis(2-ethylhexyl) sulfosuccinate, purity 98\%), was purchased from Sigma Aldrich, product number 323586.
Sorbitan monostearate (Span 60) was purchased from TCI, product number GL01-YQ. Tween 80 was purchased from Schuchardt München (now Merck). Sodium dodecyl sulfate (SDS), purity $\geq 99.0 \%$ (GC), was purchased from Sigma Aldrich, product number L6026. Triton X-100 was purchased from Sigma Aldrich, product number T9284. TPGS-750-M (DL- $\alpha-$ tocopherol methoxypolyethylene glycol succinate) was purchased from Sigma Aldrich, product number 763896. Hexadecyltrimethylammonium bromide (CTAB), purity $\geq 99.0 \%$, was purchased from Sigma Aldrich, product number H9151. The remaining starting materials were purchased from Sigma Aldrich or TCI.

\section{General procedure for the synthesis of products $5 a-r$ (with SDS as additive)}

An alcohol ( $0.5 \mathrm{mmol})$, laccase from Trametes versicolor $(20 \mathrm{mg})$, TEMPO $(0.1 \mathrm{mmol})$, and SDS $(0.1 \mathrm{mmol})$ were stirred in phosphate buffer ( $5 \mathrm{ml}, \mathrm{pH} 5.2, c=0.1 \mathrm{M})$ at room temperature. After $24 \mathrm{~h}$, an amine $(0.5 \mathrm{mmol})$, carboxylic acid $(0.5 \mathrm{mmol})$, and isocyanide $(0.5 \mathrm{mmol})$ were added and the mixture was stirred for an additional $48 \mathrm{~h}$. The reaction was carried out in an open vessel. After extraction with ethyl acetate or dichloromethane (3 $\times 20 \mathrm{~mL}$ ), the resulting combined organic layers were dried with $\mathrm{MgSO}_{4}$ and then, the solvent was removed by distillation under reduced pressure. The product was purified by column chromatography (silica gel, hexane/AcOEt; $6: 4 / \mathrm{v} / \mathrm{v}$ ). The NMR spectra are given in the ESI. $\dagger$

6a $N$-[(4-Methoxyphenyl)methyl]-2-[(4-methoxyphenyl)methyl(2-phenylacetylo)amino]-2-phenylacetamide

Pale yellow oil; ${ }^{1} \mathrm{H}$ NMR (400 MHz, $\left.\mathrm{CDCl}_{3}\right) \delta 7.14-7.25(10 \mathrm{H}, \mathrm{m}$, $\mathrm{Ph})$, 7.04-7.10 (2H, m, Ph), 6.84 (2H, m, Ph), $6.73(2 \mathrm{H}, \mathrm{m}, \mathrm{Ph})$, $6.64(2 \mathrm{H}, \mathrm{m}, \mathrm{Ph}), 6.03(1 \mathrm{H}, \mathrm{s}$ br, NH$), 5.78(1 \mathrm{H}, \mathrm{s}, \mathrm{CH}), 4.60(1 \mathrm{H}$, $\left.\mathrm{m}, \mathrm{CH}_{\mathrm{a}}\right), 4.40\left(1 \mathrm{H}, \mathrm{m}, \mathrm{CH}_{\mathrm{b}}\right), 4.27\left(2 \mathrm{H}, \mathrm{m}, \mathrm{CH}_{2}\right), 3.68(6 \mathrm{H}, \mathrm{m}, 2 \times$ $\left.\mathrm{CH}_{3}\right), 3.61\left(2 \mathrm{H}, \mathrm{m}, \mathrm{CH}_{2}\right) .{ }^{13} \mathrm{C} \mathrm{NMR}\left(100 \mathrm{MHz} ; \mathrm{CDCl}_{3}\right) \delta \mathrm{ppm}=$ 40.9, 42.8, 54.8, 54.9, 63.1, 113.5, 113.6, 126.4, 127.1, 127.1, 128.2 , 128.2, 128.2, 128.3, 128.4, 128.4, 128.5, 128.5, 128.6, $128.7,129.3,134.3,158.3,169.0,172.4$; HRMS calcd for $\mathrm{C}_{32} \mathrm{H}_{32} \mathrm{~N}_{2} \mathrm{O}_{4} \mathrm{Na}[\mathrm{M}+\mathrm{Na}]^{+}: 521.2255$ found: 531.2260 .

\section{6b $N$-[(4-Methoxyphenyl)methyl]-2-[(4-methoxyphenyl) methyl(2-phenylacetylo)amino]-2-[4-methylphenyl]acetamide}

Pale yellow oil; ${ }^{1} \mathrm{H}$ NMR $\left(400 \mathrm{MHz}, \mathrm{CDCl}_{3}\right) \delta 7.05-7.22(9 \mathrm{H}, \mathrm{m}$, $\mathrm{Ph}), 6.96-6.98$ (2H, m, Ph), 6.86-6.88 (2H, m, Ph), 6.72-6.75 (2H, $\mathrm{m}, \mathrm{Ph}), 6.65-6.67(2 \mathrm{H}, \mathrm{m}, \mathrm{Ph}), 5.90(1 \mathrm{H}, \mathrm{s} \mathrm{br}, \mathrm{NH}), 5.67(1 \mathrm{H}, \mathrm{s}$, $\mathrm{CH})$, 4.56-4.60 (1H, m, $\left.\mathrm{CH}_{\mathrm{a}}\right), 4.38-4.29\left(3 \mathrm{H}, \mathrm{m}, \mathrm{CH}_{2}+\mathrm{CH}_{\mathrm{b}}\right)$, 3.59-3.70 (6H, m, $\left.2 \times \mathrm{CH}_{3}+\mathrm{CH}_{2}\right), 2.20\left(3 \mathrm{H}, \mathrm{s}, \mathrm{CH}_{3}\right) .{ }^{13} \mathrm{C} \mathrm{NMR}$ $\left(100 \mathrm{MHz} ; \mathrm{CDCl}_{3}\right) \delta \mathrm{ppm}=20.9,41.1,43.0,55.1$, 55.1, 63.1, $113.7,113.8,128.4$, 128.8, 128.8, 128.9, 129.3, 129.5, 134.7, 138.2, 158.6, 169.5, 172.6; HRMS calcd for $\mathrm{C}_{33} \mathrm{H}_{34} \mathrm{~N}_{2} \mathrm{O}_{4} \mathrm{Na}[\mathrm{M}+$ $\mathrm{Na}]^{+}: 545.2416$ found: 545.2418 . 
6c $N$-[(4-Methoxyphenyl)methyl]-2-[(4-methoxyphenyl)methyl(2-phenylacetylo)amino]-2-[4-methoxyphenyl] acetamide

Pale yellow oil; ${ }^{1} \mathrm{H}$ NMR (400 MHz, $\left.\mathrm{CDCl}_{3}\right) \delta 7.12-7.31(11 \mathrm{H}, \mathrm{m}$, $\mathrm{Ph}), 6.89-6.91$ (2H, m, Ph), 6.81-6.83 (2H, m, Ph), 6.73-6.75 (2H, m, Ph), 6.10 (1H, s br, NH), $5.73(1 \mathrm{H}, \mathrm{s}, \mathrm{CH}), 4.64-4.68(1 \mathrm{H}, \mathrm{m}$, $\left.\mathrm{CH}_{\mathrm{a}}\right), 4.34-4.47\left(3 \mathrm{H}, \mathrm{m}, \mathrm{CH}_{2}+\mathrm{CH}_{\mathrm{b}}\right), 3.71-3.79\left(6 \mathrm{H}, \mathrm{m}, 2 \times \mathrm{CH}_{3}\right.$ $\left.+\mathrm{CH}_{2}\right) \cdot{ }^{13} \mathrm{C}$ NMR $\left(100 \mathrm{MHz} ; \mathrm{CDCl}_{3}\right) \delta \mathrm{ppm}=43.1,50.0,55.2$, 62.5, 114.0, 126.9, 127.4, 127.4, 128.6, 128.7, 128.7, 128.8, 128.8, 129.0, 130.9, 130.9, 134.4, 134.5, 158.8, 172.8, 178.0; HRMS calcd for $\mathrm{C}_{32} \mathrm{H}_{31} \mathrm{~N}_{2} \mathrm{O}_{4} \mathrm{Na}[\mathrm{M}+\mathrm{Na}]^{+}: 565.1872$ found: 565.1873 .

6d $N$-[(4-Methoxyphenyl)methyl]-2-[(4-methoxyphenyl)methyl(2-phenylacetylo)amino]-2-[4-chlorophenyl]acetamide

Pale yellow oil; ${ }^{1} \mathrm{H}$ NMR $\left(400 \mathrm{MHz}, \mathrm{CDCl}_{3}\right) \delta 7.12-7.31(11 \mathrm{H}, \mathrm{m}$, $\mathrm{Ph})$, 6.89-6.91 (2H, m, Ph), 6.81-6.83 (2H, m, Ph), 6.73-6.75 (2H, $\mathrm{m}, \mathrm{Ph}), 6.10(1 \mathrm{H}, \mathrm{s} \mathrm{br}, \mathrm{NH}), 5.73(1 \mathrm{H}, \mathrm{s}, \mathrm{CH}), 4.64-4.68(1 \mathrm{H}, \mathrm{m}$, $\mathrm{CHa})$, 4.34-4.47 (3H, m, $\left.\mathrm{CH}_{2}+\mathrm{CH}_{\mathrm{b}}\right), 3.71-3.79\left(6 \mathrm{H}, \mathrm{m}, 2 \times \mathrm{CH}_{3}\right.$ $\left.+\mathrm{CH}_{2}\right) \cdot{ }^{13} \mathrm{C}$ NMR $\left(100 \mathrm{MHz} ; \mathrm{CDCl}_{3}\right) \delta \mathrm{ppm}=43.1,50.0,55.2$, 62.5, 114.0, 126.9, 127.4, 127.4, 128.6, 128.7, 128.7, 128.8, 128.8, 129.0, 130.9, 130.9, 134.4, 134.5, 158.8, 172.8, 178.0; HRMS calcd for $\mathrm{C}_{32} \mathrm{H}_{31} \mathrm{ClN}_{2} \mathrm{O}_{4} \mathrm{Na}[\mathrm{M}+\mathrm{Na}]^{+}$: 493.2464 found: 493.2467 .

6e $N$-[(4-Methoxyphenyl)methyl]-2-[(4-methoxyphenyl)methyl(2-phenylacetylo)amino]-2-[4-bromophenyl]acetamide

Pale yellow oil; ${ }^{1} \mathrm{H}$ NMR (400 MHz, $\left.\mathrm{CDCl}_{3}\right) \delta 7.12-7.36(12 \mathrm{H}, \mathrm{m}$, $\mathrm{Ph}), 6.89-6.91$ (2H, m, Ph), 6.84-6.81 (2H, m, Ph), 6.75-6.73 (2H, $\mathrm{m}, \mathrm{Ph}), 6.13(1 \mathrm{H}, \mathrm{s} \mathrm{br}, \mathrm{NH}), 5.71(1 \mathrm{H}, \mathrm{s}, \mathrm{CH}), 4.64-4.68(1 \mathrm{H}, \mathrm{m}$, $\left.\mathrm{CH}_{\mathrm{a}}\right), 4.34-4.47\left(3 \mathrm{H}, \mathrm{m}, \mathrm{CH}_{2}+\mathrm{CH}_{\mathrm{b}}\right), 3.71-3.79\left(8 \mathrm{H}, \mathrm{m}, 2 \times \mathrm{CH}_{3}\right.$ $\left.+\mathrm{CH}_{2}\right) \cdot{ }^{13} \mathrm{C}$ NMR $\left(100 \mathrm{MHz} ; \mathrm{CDCl}_{3}\right) \delta \mathrm{ppm}=41.2,43.1,50.0$, 55.2, 62.4, 113.9, 122.5, 126.9, 127.4, 127.4, 128.6, 128.8, 128.8, 129.0, 131.2, 131.6, 134.4, 151.2, 158.8, 168.8, 172.7; HRMS calcd for $\mathrm{C}_{32} \mathrm{H}_{31} \mathrm{BrN}_{2} \mathrm{O}_{4} \mathrm{Na}[\mathrm{M}+\mathrm{Na}]^{+}: 467.2311$ found: 467.2309 .

6g $N$-[(4-Methoxyphenyl)methyl]-2-[(4-methoxyphenyl)methyl(2-phenylacetylo)amino]-2-propionamide

White powder; mp. 94-95 ${ }^{\circ} \mathrm{C} ;{ }^{1} \mathrm{H}$ NMR $\left(400 \mathrm{MHz} ; \mathrm{CDCl}_{3}\right) \delta \mathrm{ppm}$ $=7.13-7.17(4 \mathrm{H}, \mathrm{m}, \mathrm{Ph}), 6.96-7.05(5 \mathrm{H}, \mathrm{m}, \mathrm{Ph}), 6.65-7.77(5 \mathrm{H}$, $\mathrm{m}, \mathrm{Ph}+\mathrm{CH}), 4.94-4.99(1 \mathrm{H}, \mathrm{m}, \mathrm{NH}), 4.37-4.49(2 \mathrm{H}, \mathrm{q}, J=$ 17.7 Hz, $\left.\mathrm{CH}_{2}\right), 4.15-4.17\left(2 \mathrm{H}, \mathrm{d}, J=5.5 \mathrm{~Hz}, \mathrm{CH}_{2}\right), 3.69(6 \mathrm{H} \mathrm{s}, 2 \times$ $\left.\mathrm{CH}_{3}\right), 3.52-3.54\left(2 \mathrm{H}, \mathrm{m}, \mathrm{CH}_{2}\right), 1.18-1.26\left(3 \mathrm{H}, \mathrm{m}, \mathrm{CH}_{3}\right) ;{ }^{13} \mathrm{C} \mathrm{NMR}$ $\left(100 \mathrm{MHz} ; \mathrm{CDCl}_{3}\right) \delta \mathrm{ppm}=14.0,41.0,42.7,42.7,47.8,53.2,55.1$, $113.8,114.1,126.8,126.9$, 128.5, 128.7, 128.8, 129.0, 129.1, 130.2, 134.4, 158.8, 170.9, 172.9; HRMS calcd for $\mathrm{C}_{27} \mathrm{H}_{30} \mathrm{~N}_{2} \mathrm{O}_{4} \mathrm{Na}$ $[\mathrm{M}+\mathrm{Na}]^{+}: 469.2103$ found: 469.2099 .

6i $N$-[(4-Methoxyphenyl)methyl]-2-[(4-methoxyphenyl)methyl(2-phenylacetylo)amino]-2-dodecanamide

Yellow powder; mp. 92-93 ${ }^{\circ} \mathrm{C} ;{ }^{1} \mathrm{H}$ NMR $\left(400 \mathrm{MHz} ; \mathrm{CDCl}_{3}\right) \delta \mathrm{ppm}$ $=7.17-7.19(4 \mathrm{H}, \mathrm{m}, \mathrm{Ph}), 6.97-7.02(5 \mathrm{H}, \mathrm{m}, \mathrm{Ph}), 6.77-7.74(5 \mathrm{H}$, $\mathrm{m}, \mathrm{Ph}+\mathrm{CH}), 4.76-4.79(1 \mathrm{H}, \mathrm{m}, \mathrm{NH}), 4.46\left(2 \mathrm{H}, \mathrm{s}, \mathrm{CH}_{2}\right), 4.16-4.22$ $\left(2 \mathrm{H}, \mathrm{q}, J=17.2 \mathrm{~Hz} \mathrm{CH}_{2}\right), 3.72\left(6 \mathrm{H} \mathrm{s}, 2 \times \mathrm{CH}_{3}\right), 3.55-3.56(2 \mathrm{H}, \mathrm{m}$, $\left.\mathrm{CH}_{2}\right), 1.11-1.21\left(20 \mathrm{H}, \mathrm{m}, \mathrm{CH}_{2}\right), 0.79-0.83\left(3 \mathrm{H}, \mathrm{m}, \mathrm{CH}_{3}\right) ;{ }^{13} \mathrm{C}$ NMR (100 MHz; $\left.\mathrm{CDCl}_{3}\right) \delta \mathrm{ppm}=14.0,22.6,26.4,28.3$, 29.3, 29.4, 29.4, 29.5, 31.9, 41.3, 42.8, 42.8, 48.3, 55.2, 58.5, 114.0, 114.2 , 126.9, 127.3, 128.6, 128.7, 128.9, 129.0, 129.2, 130.3,
134.5, 158.9, 170.4, 173.3; HRMS calcd for $\mathrm{C}_{36} \mathrm{H}_{48} \mathrm{~N}_{2} \mathrm{O}_{4} \mathrm{Na}[\mathrm{M}+$ $\mathrm{Na}]^{+}: 483.2260$ found: 483.2256 .

\section{6j $N$-Benzyl-2-[(4-methoxyphenyl)methyl-(2-phenylacetylo)} amino]-2-phenylacetamide

Pale yellow oil; ${ }^{1} \mathrm{H}$ NMR (400 MHz, $\left.\mathrm{CDCl}_{3}\right) \delta 7.09-7.27(15 \mathrm{H}, \mathrm{m}$, $\mathrm{Ph})$, 6.83-6.85 (2H, m, Ph), 6.62-6.64 (2H, m, Ph), 6.05 (1H, s br, $\mathrm{NH}), 5.73(1 \mathrm{H}, \mathrm{s}, \mathrm{CH}), 4.54-4.57\left(1 \mathrm{H}, \mathrm{m}, \mathrm{CH}_{\mathrm{a}}\right), 4.36-4.37(3 \mathrm{H}, \mathrm{m}$, $\left.\mathrm{CH}_{2}+\mathrm{CH}_{\mathrm{b}}\right), 3.61-3.71\left(5 \mathrm{H}, \mathrm{m}, \mathrm{CH}_{3}+\mathrm{CH}_{2}\right) ;{ }^{13} \mathrm{C} \mathrm{NMR}(100 \mathrm{MHz}$; $\left.\mathrm{CDCl}_{3}\right) \delta \mathrm{ppm}=43.1,43.5,55.1,55.1,66.8,113.7,127.2,127.5$, 128.4, 128.5, 128.6, 128.7, 128.8, 129.7, 134.6, 158.6, 172.6, 174.1, HRMS calcd for $\mathrm{C}_{31} \mathrm{H}_{30} \mathrm{~N}_{2} \mathrm{O}_{3} \mathrm{Na}[\mathrm{M}+\mathrm{Na}]^{+}: 501.2154$ found: 501.2154 .

6k $N$-Cyclohexyl-2-[(4-methoxyphenyl)methyl-(2-phenylacetylo) amino]-2-phenylacetamide

Pale yellow oil; ${ }^{1} \mathrm{H}$ NMR (400 MHz, $\left.\mathrm{CDCl}_{3}\right) \delta 7.19-7.42(10 \mathrm{H}, \mathrm{m}$, $\mathrm{Ph}), 6.84-6.86$ (2H, m, Ph), 6.68-6.65 (2H, m, Ph), 5.76 (1H, s br, $\mathrm{NH}), 5.54(1 \mathrm{H}, \mathrm{s}, \mathrm{CH}), 4.57-4.62\left(1 \mathrm{H}, \mathrm{d}, J=17.9 \mathrm{~Hz}, \mathrm{CH}_{\mathrm{a}}\right), 4.36-$ $4.41\left(1 \mathrm{H}, \mathrm{d}, J=17.6 \mathrm{~Hz}, \mathrm{CH}_{\mathrm{b}}\right), 3.60-3.69\left(5 \mathrm{H}, \mathrm{m}, \mathrm{CH}_{3}+\mathrm{CH}_{2}\right)$, $1.81\left(2 \mathrm{H}, \mathrm{m}, \mathrm{CH}_{2}\right), 1.51\left(2 \mathrm{H}, \mathrm{m}, \mathrm{CH}_{2}\right), 1.26-1.19\left(2 \mathrm{H}, \mathrm{m}, \mathrm{CH}_{2}\right)$, 0.99 (2H, m, $\left.\mathrm{CH}_{2}\right), 0.81-0.76(1 \mathrm{H}, \mathrm{m}, \mathrm{CH}) ;{ }^{13} \mathrm{C} \mathrm{NMR}(100 \mathrm{MHz}$; $\left.\mathrm{CDCl}_{3}\right) \delta \mathrm{ppm}=24.7,24.1,25.4,32.7,41.3,48.4,55.2,113.9$, 113.9 , 126.8, 127.4, 128.3, 128.4, 128.4, 128.6, 128.6, 128.6, 128.9, 128.9, 129.6, 134.8, 134.8, 158.7, 168.4, 172.7; HRMS calcd for $\mathrm{C}_{30} \mathrm{H}_{34} \mathrm{~N}_{2} \mathrm{O}_{4} \mathrm{Na}[\mathrm{M}+\mathrm{Na}]^{+}$: 493.2467 found: 493.2464 .

$61 \mathrm{~N}$-t-Butyl-2-[(4-methoxyphenyl)methyl-(2-phenylacetylo) amino]-2-phenylacetamide

Pale yellow oil; ${ }^{1} \mathrm{H}$ NMR (400 MHz, $\left.\mathrm{CDCl}_{3}\right) \delta 7.10-7.26(10 \mathrm{H}, \mathrm{m}$, $\mathrm{Ph}$ ), 6.79-6.80 (2H, m, Ph), 6.61-6.65 (2H, m, Ph), 5.82 (1H, s br, $\mathrm{NH}), 5.66(1 \mathrm{H}, \mathrm{s}, \mathrm{CH}), 4.58-4.62\left(1 \mathrm{H}, \mathrm{m}, \mathrm{CH}_{\mathrm{a}}\right), 4.41-4.45(1 \mathrm{H}, \mathrm{m}$, $\left.\mathrm{CH}_{\mathrm{b}}\right), 3.56-3.67\left(3 \mathrm{H}, \mathrm{m}, \mathrm{CH}_{3}+\mathrm{CH}_{2}\right), 1.06-1.35(10 \mathrm{H}, \mathrm{m}$, $\left.\mathrm{CH}\left(\mathrm{CH}_{3}\right) 3\right) .{ }^{13} \mathrm{C} \mathrm{NMR}\left(100 \mathrm{MHz} ; \mathrm{CDCl}_{3}\right) \delta \mathrm{ppm}=28.5,51.5,55.2$, $113.7,113.8,127.3,128.3,128.5,128.7,128.9$, 129.3, 129.4, 134.7, 158.6, 168.8, 172.9; HRMS calcd for $\mathrm{C}_{28} \mathrm{H}_{32} \mathrm{~N}_{2} \mathrm{O}_{3} \mathrm{Na}[\mathrm{M}+$ $\mathrm{Na}]^{+}: 467.2311$ found: 467.2309 .

$6 \mathrm{~m} \mathrm{N-n-Butyl-2-[(4-methoxyphenyl)methyl-(2-phenylacetylo)}$ amino]-2-phenylacetamide

Pale yellow oil; ${ }^{1} \mathrm{H}$ NMR (400 MHz, $\left.\mathrm{CDCl}_{3}\right) \delta 7.14-7.33(10 \mathrm{H}, \mathrm{m}$, $\mathrm{Ph})$, 6.91-6.93 (2H, m, Ph), 6.72-6.74 (2H, m, Ph), 6.10 (1H, s br, $\mathrm{NH}), 5.93(1 \mathrm{H}, \mathrm{s}, \mathrm{CH}), 4.67-4.71\left(1 \mathrm{H}, \mathrm{d}, J=17.5 \mathrm{~Hz}, \mathrm{CH}_{\mathrm{a}}\right), 4.54-$ $4.49\left(1 \mathrm{H}, \mathrm{d}, J=17.3 \mathrm{~Hz}, \mathrm{CH}_{\mathrm{b}}\right), 3.65-3.74\left(5 \mathrm{H}, \mathrm{m}, \mathrm{CH}_{3}+\mathrm{CH}_{2}\right)$, 3.65-3.74 (2H, m, $\left.\mathrm{CH}_{2}\right), 3.19\left(2 \mathrm{H}, \mathrm{s}, \mathrm{CH}_{2}\right), 1.22-1.38(4 \mathrm{H}, \mathrm{m}$, $\left.\mathrm{C}_{2} \mathrm{H}_{4}\right), 0.85-0.88\left(3 \mathrm{H}, \mathrm{m}, \mathrm{CH}_{3}\right) .{ }^{13} \mathrm{C} \mathrm{NMR}\left(100 \mathrm{MHz} ; \mathrm{CDCl}_{3}\right)$ $\delta \mathrm{ppm}=13.2,19.5,30.9,38.9,40.8,49.4,54.7,62.6,113.4,126.3$, $127.0,128.0$, 128.0, 128.1, 128.2, 128.5, 128.9, 129.2, 134.3, 158.2, 169.0, 172.4; HRMS calcd for $\mathrm{C}_{28} \mathrm{H}_{32} \mathrm{~N}_{2} \mathrm{O}_{3} \mathrm{Na}[\mathrm{M}+\mathrm{Na}]^{+}$: 467.2311 found: 467.2306 .

6n $N$-[(4-Methoxyphenyl)methyl]-2-[(4-methoxyphenyl)methyl3-(phenylpropionyl)amino]-2-phenylacetamide

Pale yellow oil; ${ }^{1} \mathrm{H}$ NMR $\left(400 \mathrm{MHz}, \mathrm{CDCl}_{3}\right) \delta 7.08-7.29(12 \mathrm{H}, \mathrm{m}$, $\mathrm{Ph}$ ), 6.81-6.86 (4H, m, Ph), 6.61-6.67 (2H, m, Ph), 6.14 (1H, s br, 
$\mathrm{NH}), 5.90(1 \mathrm{H}, \mathrm{s}, \mathrm{CH}), 4.59-4.63\left(1 \mathrm{H}, \mathrm{m}, \mathrm{CH}_{\mathrm{a}}\right), 4.54-4.70(3 \mathrm{H}, \mathrm{m}$, $\mathrm{CH}_{2}+\mathrm{CH}_{\mathrm{b}}$ ), 3.73-3.77 (6H, m, $\left.2 \times \mathrm{CH}_{3}\right), 2.93-2.95\left(2 \mathrm{H}, \mathrm{m}, \mathrm{CH}_{2}\right)$, 2.54-2.70 (2H, m, $\left.\mathrm{CH}_{2}\right) \cdot{ }^{13} \mathrm{C} \mathrm{NMR}\left(100 \mathrm{MHz} ; \mathrm{CDCl}_{3}\right) \delta \mathrm{ppm}=$ 31.3, 35.7, 43.1, 49.6, 55.1, 55.2, 63.2, 113.8, 113.9, 126.0, 127.3, 128.3, 128.4, 128.6, 128.9, 129.2, 129.6, 141.0, 158.5, 158.9, 169.5, 174.0; HRMS calcd for $\mathrm{C}_{33} \mathrm{H}_{34} \mathrm{~N}_{2} \mathrm{O}_{4} \mathrm{Na}[\mathrm{M}+\mathrm{Na}]^{+}: 545.2416$ found: 545.2413 .

\section{6o $N$-Benzyl-2-[(4-methoxyphenyl)methyl-4-(phenylprobutyryl)} amino]-2-phenylacetamide

${ }^{1} \mathrm{H}$ NMR (400 MHz, $\mathrm{CDCl}_{3}$ ) $\delta$ 7.16-7.32 (12H, m, Ph), 7.06-7.08 (2H, m, Ph), 6.85-6.87 (2H, m, Ph), 6.64-6.70 (3H, m, Ph + NH), 6.07 (1H, s, CH), 4.62-4.67 (1H, m, $\left.\mathrm{CH}_{\mathrm{a}}\right), 4.44-4.51\left(3 \mathrm{H}, \mathrm{m}, \mathrm{CH}_{\mathrm{b}}\right.$ $\left.+\mathrm{CH}_{2}\right), 3.73\left(3 \mathrm{H}, \mathrm{s}, \mathrm{CH}_{3}\right), 2.88-2.93\left(2 \mathrm{H}, \mathrm{m}, \mathrm{CH}_{2}\right), 2.56-2.68(2 \mathrm{H}$, $\left.\mathrm{m}, \mathrm{CH}_{2}\right) .{ }^{13} \mathrm{C} \mathrm{NMR}\left(100 \mathrm{MHz} ; \mathrm{CDCl}_{3}\right) \delta \mathrm{ppm}=31.3,35.7,43.6$, 49.6, 55.2, 63.0, 113.8, 126.0, 127.3, 127.3, 127.6, 128.4, 128.5, 128.6, 128.7, 129.5, 129.7, 135.1, 138.2, 141.0, 158.6, 169.8, 174.2; HRMS calcd for $\mathrm{C}_{32} \mathrm{H}_{32} \mathrm{~N}_{2} \mathrm{O}_{3} \mathrm{Na}[\mathrm{M}+\mathrm{Na}]^{+}: 515.2311$ found: 515.2310 .

6p $N$-[(4-Methoxyphenyl)methyl]-2-[(4-methoxyphenyl)methyl4-(phenylbutyryl)amino]-2-phenylacetamide

Pale yellow oil; ${ }^{1} \mathrm{H}$ NMR (400 MHz, $\left.\mathrm{CDCl}_{3}\right) \delta$ 6.19-6.58 $(12 \mathrm{H}, \mathrm{m}$, $\mathrm{Ph})$, 5.78-6.10 (4H, m, Ph), 6.85-6.87 (2H, m, Ph), $5.30(1 \mathrm{H}, \mathrm{s}$, $\mathrm{NH}), 5.04(1 \mathrm{H}, \mathrm{s}, \mathrm{CH}), 3.68-3.73\left(1 \mathrm{H}, \mathrm{m}, \mathrm{CH}_{\mathrm{a}}\right), 3.45-3.73(3 \mathrm{H}, \mathrm{m}$, $\left.\mathrm{CH}_{\mathrm{b}}+\mathrm{CH}_{2}\right), 2.87\left(3 \mathrm{H}, \mathrm{s}, \mathrm{CH}_{3}\right), 1.66-1.78\left(2 \mathrm{H}, \mathrm{m}, \mathrm{CH}_{2}\right), 1.28-1.49$ $\left(2 \mathrm{H}, \mathrm{m}, \mathrm{CH}_{2}\right), 1.04-1.12\left(2 \mathrm{H}, \mathrm{m}, \mathrm{CH}_{2}\right) .{ }^{13} \mathrm{C} \mathrm{NMR}(100 \mathrm{MHz}$; $\left.\mathrm{CDCl}_{3}\right) \delta \mathrm{ppm}=26.7,33.3,35.1,43.1,49.7,55.2$, 55.2, 63.2, 113.8, 114.0, 15.8, 127.4, 128.2, 128.3, 128.4, 128.5, 128.7, 129.0, 129.1, 129.7, 141.7, 158.6, 158.9, 169.6, 174.7; HRMS calcd for $\mathrm{C}_{32} \mathrm{H}_{32} \mathrm{~N}_{2} \mathrm{O}_{3} \mathrm{Na}[\mathrm{M}+\mathrm{Na}]^{+}: 506.2569$ found: 506.2566.

6r $N$-[(4-Methoxyphenyl)methyl]-2-[(4-methoxyphenyl)methyl4-(phenylpentyl)amino]-2-phenylacetamide

Pale yellow oil; ${ }^{1} \mathrm{H}$ NMR (400 MHz, $\left.\mathrm{CDCl}_{3}\right) \delta 7.24(2 \mathrm{H}, \mathrm{m}, \mathrm{Ph}$ ), 7.14-7.18 (5H, m, Ph), 7.02-7.11 (5H, m, Ph), 6.81-6.83 (2H, m, $\mathrm{Ph})$, 6.71-6.75 (2H, m, Ph), 6.61-6.63 (2H, m, Ph), $6.06(1 \mathrm{H}, \mathrm{s}$, $\mathrm{NH}), 5.82(1 \mathrm{H}, \mathrm{s}, \mathrm{CH}), 4.54-4.58\left(1 \mathrm{H}, \mathrm{d}, J=17.2 \mathrm{~Hz}, \mathrm{CH}_{\mathrm{a}}\right), 4.26-$ $4.41\left(3 \mathrm{H}, \mathrm{m}, \mathrm{CH}_{\mathrm{b}}+\mathrm{CH}_{2}\right), 3.60-3.68\left(6 \mathrm{H}, \mathrm{m}, \mathrm{CH}_{3} \times 2\right), 2.44-2.48$ $\left(2 \mathrm{H}, \mathrm{m}, \mathrm{CH}_{2}\right), 2.10-2.33\left(2 \mathrm{H}, \mathrm{m}, \mathrm{CH}_{2}\right), 1.47-1.66\left(4 \mathrm{H}, \mathrm{m}, \mathrm{C}_{2} \mathrm{H}_{4}\right)$. ${ }^{13} \mathrm{C} \mathrm{NMR}\left(100 \mathrm{MHz} ; \mathrm{CDCl}_{3}\right) \delta \mathrm{ppm}=24.7,30.9,33.8,35.6,43.1$, 49.7, 55.1, 55.2, 63.2, 113.8, 113.9, 125.6, 127.3, 128.2, 128.3, 128.3, 128.4, 128.6, 128.9, 129.1, 129.6, 142.2, 158.8; HRMS calcd for $\mathrm{C}_{34} \mathrm{H}_{36} \mathrm{~N}_{2} \mathrm{O}_{3} \mathrm{Na}[\mathrm{M}+\mathrm{Na}]^{+}: 520.2726$ found: 520.2722 .

\section{Conflicts of interest}

There are no conflicts to declare.

\section{Acknowledgements}

We gratefully acknowledge the financial support of the Polish State Committee for Scientific Research project OPUS No. 2016/ 23/B/ST5/03307 for financial support.

\section{Notes and references}

1 S. B. Lawrenson, R. Arav and M. North, Green Chem., 2017, 19, 1685.

2 R. C. Cioc, E. Ruijter and R. V. A. Orru, Green Chem., 2014, 16, 2958; Y. Gu, Green Chem., 2014, 16, 2958.

3 I. Ugi, B. Werner and A. Dömling, Molecules, 2003, 8, 53.

4 R. Wamg and Z.-Q. Liu, J. Org. Chem., 2013, 78, 8696.

5 K. Rossen, P. J. Pye, L. M. DiMichele, R. P. Volante and P. K. Reider, Tetrahedron Lett., 1998, 39, 6823.

6 I. Ugi and C. Steinbrückner, US Pat. 3247200, 1966.

7 C. Hulme and V. Gore, Curr. Med. Chem., 2003, 10, 51.

8 R. J. K. Taylor, M. Reid, J. Foot and S. A. Raw, Acc. Chem. Res., 2005, 38, 851.

9 M. Davi and H. Lebel, Org. Lett., 2009, 11, 41.

10 B. E. Maki and K. A. Sheidt, Org. Lett., 2009, 11, 1651.

11 W. L. F. Armarego and C. L. L. Chai, Purification of Laboratory Chemicals, Elsevier, Amsterdam, 6th edn, 2009, vol. 2, p. 71.

12 S. V. Ley, J. Norman, W. P. Griffith and S. P. Marsden, Synthesis, 1994, 639.

13 I. E. Markó, P. R. Giles, M. Tsukazaki, I. Chélle-Regnaut, C. J. Urch and S. M. Brown, J. Am. Chem. Soc., 1997, 119, 12661.

14 I. E. Markó, A. Gautier, P. R. Giles, I. Chélle-Regnaut, M. Tsukazaki, C. J. Urch and S. M. Brown, J. Org. Chem., 1998, 63, 7576.

15 I. E. Markó, P. R. Giles, M. Tsukazaki, I. Chélle-Regnaut, A. Gautier, S. M. Brown and C. J. Urch, J. Org. Chem., 1999, 64, 2433.

16 M. F. Semmelhack, C. R. Schmidt, D. A. Cortés and C. S. Chou, J. Am. Chem. Soc., 1984, 106, 3374.

17 D. Paprocki, D. Koszelewski, A. Żąłło, P. Walde and R. Ostaszewski, RSC Adv., 2016, 6, 68231.

18 T. Ngouansavanh and J. Zhu, Angew. Chem., Int. Ed., 2006, 45, 3495.

19 J. Brioche, G. Masson and J. Zhu, Org. Lett., 2010, 12, 1432.

20 G. Jiang, J. Chen, J.-S. Huang and C.-M. Che, Org. Lett., 2009, 11, 4568.

21 T. Ngouansavanh and J. Zhu, Angew. Chem., Int. Ed., 2007, 46, 5775 .

22 F. Drouet, G. Masson and J. Zhu, Org. Lett., 2013, 15, 2854.

23 M. Frigerio, M. Santagostino and S. Sputore, J. Org. Chem., 1999, 64, 4537.

24 M. Fabbrini, C. Galli, P. Gentili and D. Macchitella, Tetrahedron Lett., 2001, 42, 7551.

25 M. Gupta, S. Paul and R. Gupta, Curr. Sci., 2010, 99, 1341.

26 S. M. C. Pirrung and K. Das Sarma, J. Am. Chem. Soc., 2003, 126, 444.

27 K. Atul, K. G. Maneesh and K. Mukesh, Tetrahedron Lett., 2011, 52, 4521.

28 D. G. Blackmond, A. Armstrong, V. Coombie and A. Wells, Angew. Chem., Int. Ed., 2007, 46, 3798.

29 T. Dwars, E. Paetzold and G. Oehme, Angew. Chem., Int. Ed., 2005, 44, 7174.

30 P. Walde, H. Umakoshi, P. Stano and F. Mavelli, Chem. Commun., 2014, 50, 10177. 
31 P. Walde, Origins Life Evol. Biospheres, 2006, 36, 109.

32 K. W. Wellington, R. Bokako, N. Raseroka and P. Steenkamp, Green Chem., 2012, 14, 2567.

33 E. Brenna, M. Crotti, F. G. Gatti, D. Monti, F. Parmeggiani, A. Pugliese and F. Tentori, Green Chem., 2017, 19, 5122.

34 L. Martínez-Montero, V. Gotor, V. Gotor-Fernandez and I. Lavanderá, ACS Catal., 2018, 8, 2413.

35 Y.-Z. Qin, Y.-M. Li, M.-H. Zong, H. Wu and N. Li, Green Chem., 2015, 17, 3718.

36 L. Martínez-Montero, V. Gotor, V. Gotor-Fernández and I. Lavandera, Green Chem., 2017, 19, 474.

37 J. Albarrán-Velo, M. López-Iglesias, V. Gotor, V. GotorFernández and I. Lavandera, RSC Adv., 2017, 7, 50459.

38 P. Galletti, F. Funiciello, R. Soldati and D. Giacomini, Adv. Synth. Catal., 2015, 357, 1840.

39 A. Madej, D. Paprocki, D. Koszelewski, A. ZadloDobrowolska, A. Brzozowska, P. Walde and R. Ostaszewski, RSC Adv., 2017, 7, 33344.

40 M. Fabbini, C. Galli, P. Gentili and D. Macchitella, Tetrahedron Lett., 2001, 42, 7551.

41 S. A. Tromp, I. Matijoš̀te, R. A. Sheldon, I. W. C. E. Arends, G. Mul, M. T. Kreutzer, J. A. Moulijn and S. de Vries, ChemCatChem, 2010, 2, 827.
42 P. Mukerjee and K. J. Mysels, Critical Micelle Concentration of Aqueous Surfactant Systems, NSRDS-NBS 36, Government Printing Office, Washington, DC, US, 1971.

43 O. V. Morozova, G. P. Shumakovich, S. V. Shleev and Y. I. Yaropolov, Appl. Biochem. Microbiol., 2007, 43, 583.

44 M. J. Han, H. T. Choi and H. G. Song, J. Microbiol., 2005, 43, 555.

45 L. A. Beaudette, O. P. Ward, M. A. Pickard and P. M. Fedorak, Lett. Appl. Microbiol., 2000, 30, 155.

46 J. Michizoe, H. Ichinose, N. Kamiya, T. Maruyama and M. Goto, J. Biosci. Bioeng., 2005, 99, 642.

47 P.-P. Champagne, M. E. Nesheim and J. A. Ramsay, Enzyme Microb. Technol., 2010, 46, 147.

48 P. Baiocco, A. M. Barreca, M. Fabbrini, C. Galli and P. Gentili, Org. Biomol. Chem., 2013, 1, 191.

49 M. Fabbrini, C. Galli, P. Gentili and D. Macchitella, Tetrahedron Lett., 2001, 42, 7551.

50 P. Galletti, F. Funiciello, R. Soldati and D. Giacomini, Adv. Synth. Catal., 2015, 357, 1840.

51 F. Carunchio, C. Crescenzi, A. M. Girelli, A. Messina and A. M. Tarola, Talanta, 2001, 55, 189.

52 N. Shapiro and A. Vigalok, Angew. Chem., 2008, 120, 2891.

53 M. Mąkosza, Elsevier, 1980, 9, 1. 